\title{
Photosensitizers from Spirulina for Solar Cell
}

\author{
Liqiu Wang, ${ }^{1}$ Liang Tian, ${ }^{1}$ Xinxin Deng, ${ }^{1}$ Mengyi Zhang, ${ }^{2}$ \\ Shuping Sun, ${ }^{1}$ Wei Zhang, ${ }^{1}$ and Lin Zhao' \\ ${ }^{1}$ College of Environmental and Chemical Engineering, Yanshan University, Qinhuangdao, Hebei 066004, China \\ ${ }^{2}$ College of Life Sciences, Nankai University, Tianjin 300071, China
}

Correspondence should be addressed to Liqiu Wang; liqiuwang@tom.com

Received 8 November 2013; Accepted 11 December 2013; Published 2 February 2014

Academic Editor: Xinqing Chen

Copyright ( 2014 Liqiu Wang et al. This is an open access article distributed under the Creative Commons Attribution License, which permits unrestricted use, distribution, and reproduction in any medium, provided the original work is properly cited.

\begin{abstract}
Spirulina is a kind of blue-green algae with good photosynthetic efficiency and might be used for photovoltaic power generation. So this paper used living spirulina as novel photosensitizer to construct spirulina biosolar cell. The results showed that spirulina had the photoelectric conversion effect, and could let the spirulina biosolar cell have $70 \mu \mathrm{A}$ photocurrent. Meanwhile, adding glucose sucrose or chitosan in the spirulina anode chamber, they could make the maxima current density of the cell greatly increased by $80 \mu \mathrm{A}, 100 \mu \mathrm{A}$, and $84 \mu \mathrm{A}$, respectively, and the sucrose could improve the maximum power density of the cell to $63 \mathrm{~mW} / \mathrm{m}^{-2}$. Phycobiliprotein played an important role in the photosynthesis of spirulina. So in this paper phycobiliprotein was extracted from spirulina to composite with squaraine dye to sensitize nanocrystalline $\mathrm{TiO}_{2}$ photoanode for building dye sensitized solar cell, and the photoelectric properties of the cell also were investigated.
\end{abstract}

\section{Introduction}

Many photosensitizers [1-4] have been used to construct photo devices, such as organic dyes, inorganic nanomaterials, and biomass. Solar cells are the main photo devices that achieve the conversion of light energy into electrical energy. In particular, the solar cells based on photosynthesis principle of plants and algae, have great potential for the development and application [5-9]. In 1911, British botanist Potter discovered that microbes could produce current [10]. After the 1980s, electron transfer intermediates were widely used for improving output power of the microbial fuel cell greatly. In 1999, Tatsuo Yagishita et al. studied Synechococcus with glucose to make electricity production [11]. Researchers in University of Massachusetts found that iron reducing bacteria Rhodospirillum could metabolize carbohydrates and produce electricity [12]. US scientist Logan injected new vitality to the research of microbial fuel cell (MFC) by his studies in wastewater treatment and microbiological power generation [13-17]. Spirulina is ancient blue-green algae [18], and the growth and expansion of spirulina are rapid, easy, and convenient due to its cultivation $\mathrm{pH}$ 8.6-9.5 and lower demands for the environment $[19,20]$. It has the solar energy utilization efficiency up to $18 \%$ and the photosynthetic efficiency up to $43 \%$ (more than 3 times high to those of advanced plants) due to its phycobiliprotein. So this paper intended to extract phycobiliprotein from spirulina and used it as photosensitizer to sensitize nano- $\mathrm{TiO}_{2}$ to equip the dye sensitized solar cell [21]. Meanwhile, we applied the living spirulina to build the spirulina biosolar cell $[22,23]$ and investigated the electrical properties of the cell and the influence of carbohydrates on photoelectric performance of the cell.

\section{Experimental}

2.1. Spirulina Cultivation and Extraction of Phycobiliprotein. Spirulina was cultivated with medium Zarrouk or medium spirulina at $28^{\circ} \mathrm{C}$ under $3000 \mathrm{~lx}$ light and $12 \mathrm{~L} / 12 \mathrm{D}$ photoperiod and was trained for 20 days [24] for the experiment. Phycobiliprotein was extracted from the spirulina by repeated freezing and melting technology under ultrasonic.

2.2. $\mathrm{TiO}_{2}$ Film and Its Sensitization with the Phycobiliprotein and Phycobiliprotein Squaraine. Nanometer $\mathrm{TiO}_{2}$ film was prepared on glass electrode by sol-gel from butyl titanate, 


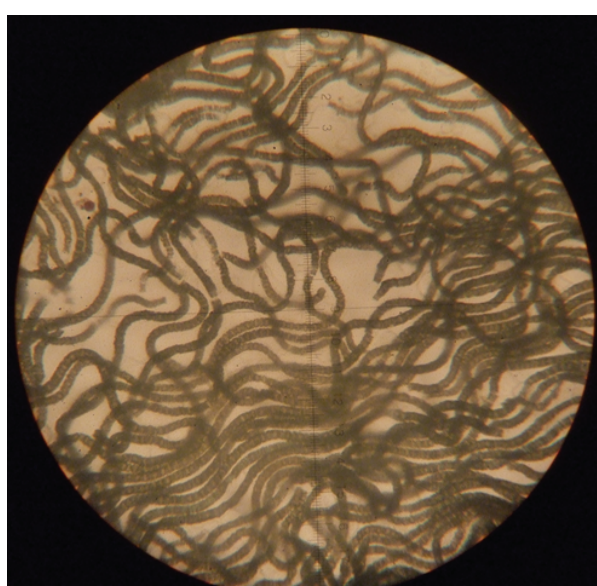

(a)

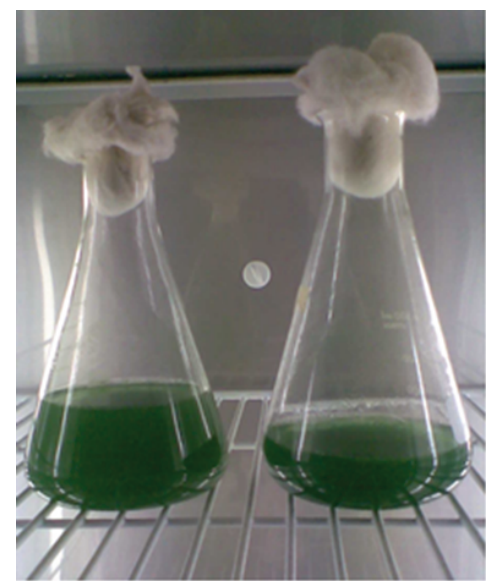

(b)

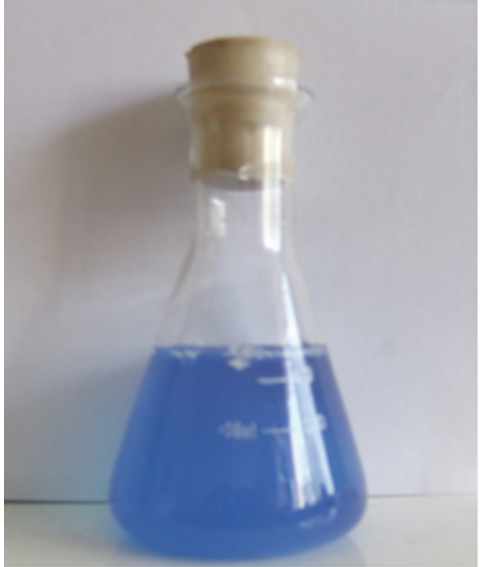

(c)

FIgURE 1: The sample of live spirulina under microscope (a) and in incubator (b) and the phycobiliprotein extracted (c).

diethanolamine, ethyl alcohol, and PEG and was sensitized with the phycobiliprotein or phycobiliprotein squaraine by impregnated method, respectively. The squaraine dye with $\mathrm{N}$-p-carboxybenzyl group was synthesized by the reference [25].

2.3. Construction of Spirulina Biosolar Cell. Spirulina biosolar cell consisted of anode chamber and cathode chamber separated by clapboard, and the clapboard was equipped with proton exchange membrane (Nafion, $14 \mathrm{~cm}^{2}$ ). Two graphite electrodes in the anode and cathode chamber (about $10 \mathrm{~cm}^{2}$ ) were placed closely to both sides of the proton exchange membrane, and $\mathrm{Ag} / \mathrm{AgCl}$ reference electrode in the anode chamber was close to the anode. Spirulina in the culture medium $(240 \mathrm{~mL})$ with or without glucose, sucrose, or chitosan was added to the anode chamber, while the culture medium $(240 \mathrm{~mL})$ was in the cathode chamber.

\subsection{Detection of the Spirulina Biosolar Cell. The spirulina} biosolar cell was placed under a xenon light source with the distance of $22 \mathrm{~cm}$ to the surface of anolyte. Photoelectric conversion performance of the solar cell was detected at $28^{\circ} \mathrm{C}$ under xenon lamp by electrochemical workstation.

\section{Results and Discussion}

3.1. Spirulina and Phycobiliprotein Photosensitizers. Figure 1 showed that the spirulina cultivated was green and spirochete, while the phycobiliprotein extracted from spirulina was blue. The maximum fluorescence emission wavelength of the phycobiliprotein was $650 \mathrm{~nm}$. The phycobiliprotein sensitized the nano- $\mathrm{TiO}_{2}$ film anode and assembled it into the dye sensitized solar cell with $\mathrm{KI} / \mathrm{I}_{2}$ acetonitrile solution as electrolyte and graphite as cathode. The results showed that the phycobiliprotein could improve the photovoltage and current of the nano- $\mathrm{TiO}_{2}$ film to $273 \mathrm{mV}$ and $4.2 \mathrm{~mA}$, while using the phycobiliprotein squaraine as the photosensitizer, they could be $407 \mathrm{mV}$ and $5.7 \mathrm{~mA}$.

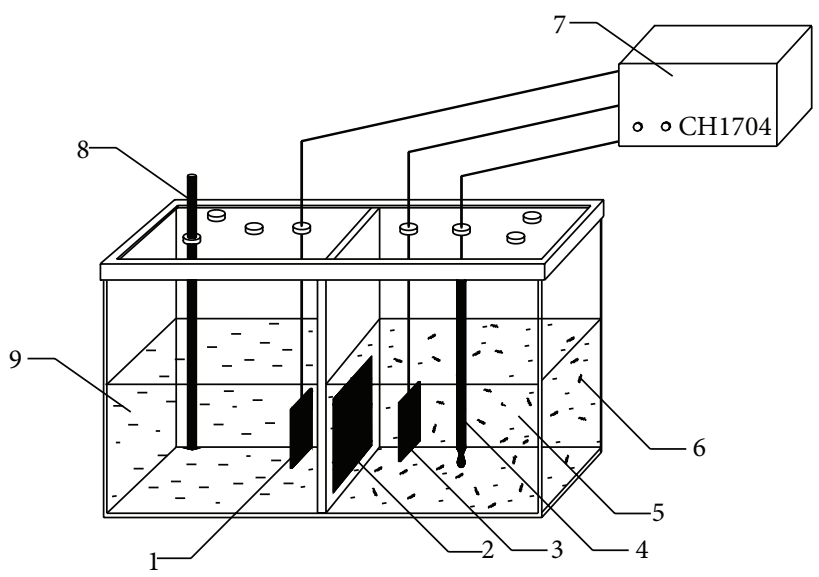

FIGURE 2: Schematic structure of the spirulina biosolar cell. 1: cathode, 2: proton exchange membrane, 3: anode, 4: reference electrode, 5: anolyte, 6: spirulina, 7: electrochemical workstation, 8: intake tube, and 9: catholyte.

3.2. The Spirulina Biosolar Cell and Its Working Principle. Structure and working principle of the spirulina biosolar cell were shown in Figures 2 and 3. Spirulina as electricity generation algae in the anolyte emitted electrons by its photosynthesis and respiration metabolism under light, and the electrons were transferred to the anode. At the same time, the protons were produced, then transferred to the cathode surface after penetrating the proton exchange membrane, and at last the protons reacted with oxygen and electrons to form water.

3.3. Photocurrent of the Spirulina Biosolar Cell. Figure 4 showed changing curves of the current with time for the cells under the dark and light. B1 represented the curve for the cell with $240 \mathrm{~mL}$ culture medium in each of the chambers, while S1 for the cell with $240 \mathrm{~mL}$ spirulina cultivated for twenty days in anode chamber and $240 \mathrm{~mL}$ culture medium in 


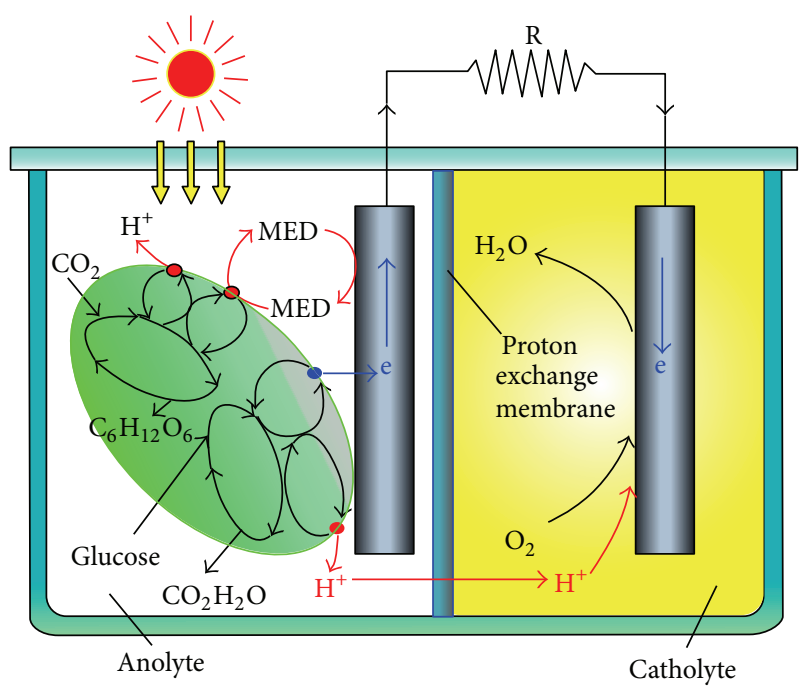

FIGURE 3: Electrons transfer mechanism of the spirulina biosolar cell.

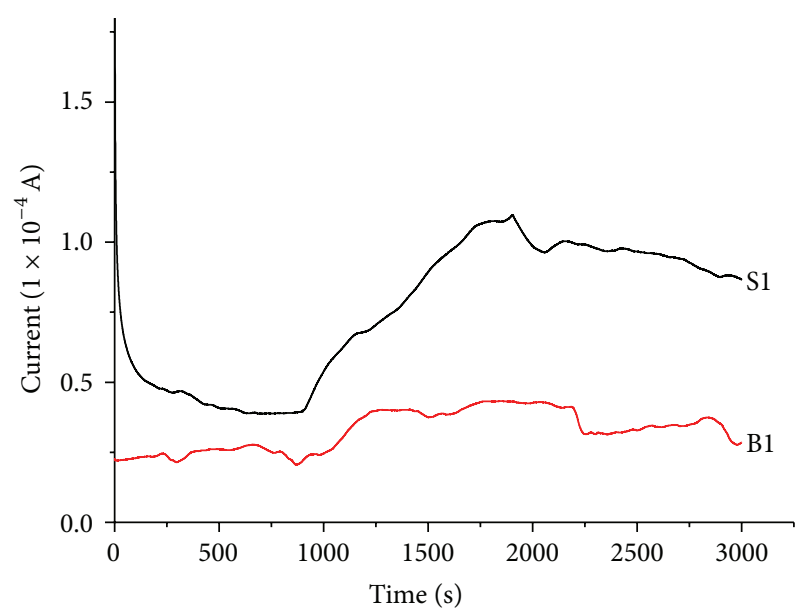

FIGURE 4: Current-time curves of the solar cell with and without spirulina under light and dark. B1: without spirulina; S1: with spirulina.

the cathode chamber. There was no light in $900 \mathrm{~s}$. When lighting at the $900 \mathrm{~s}$, the current rose, and fell when the lighting was removed at the $1900 \mathrm{~s}$. B1 indicated that polarization current of the cell increased $19 \mu \mathrm{A}$ due to the elevated temperature of the solution and the reduction of internal resistance in solution under the illumination. The current of the cell under illumination had largely been increased (S1) by $70 \mu \mathrm{A}$ due to the electron produced from spirulina by photosynthesis, and after the light was removed, the current decreased a little. Figure 5 showed that the current of the spirulina biosolar cell should be increased by $240 \mu \mathrm{A}$ under the light for $6 \mathrm{~h}$.

3.4. Influence of Carbohydrates on Photocurrent of the Solar Cell. Figure 6 showed the influence of carbohydrates on photocurrent of the spirulina biosolar cell under the dark

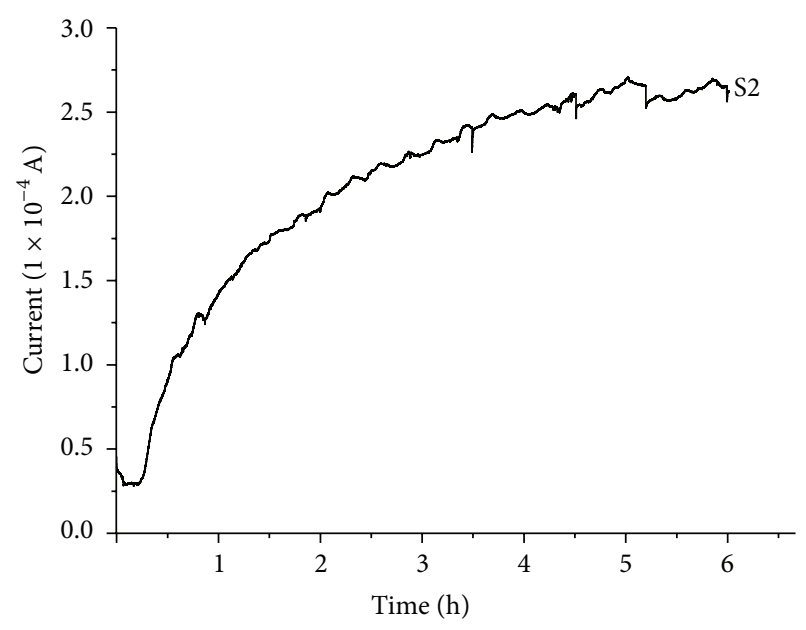

FIgURE 5: Current-time curve of the spirulina biosolar cell under the light for $6 \mathrm{~h}$.

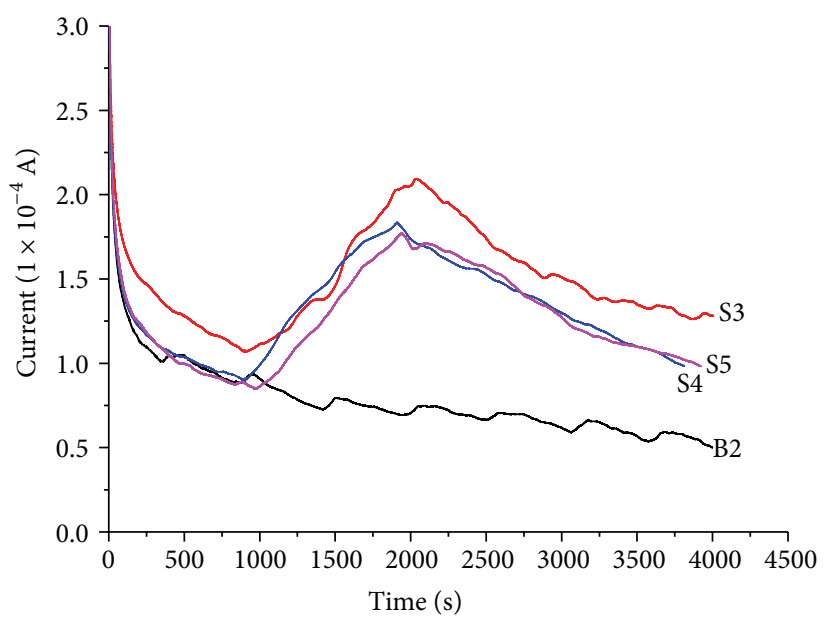

FIGURE 6: Current-time curves of the solar cell with sucrose in the anode chamber under the light and dark for three times. With spirulina, S3: the first time, S4: the second time, S5: the third time; B2: without spirulina.

and light. B2 indicated the changing of current with time for the cell with $2 \mathrm{~g}$ sucrose in $240 \mathrm{~mL}$ culture medium anode chamber. $\mathrm{S} 3$ showed that the current generated by the spirulina biosolar cell with $2 \mathrm{~g}$ sucrose in anode chamber had been increased by $100 \mu \mathrm{A}$ and indicated that the presence of sucrose could promote the electrons production significantly in photosynthesis of spirulina. After the light was removed, the current of the cell had a slight decrease. S4 and S5 explained that the maxima current only had a little decrease while repeating the experiments due to the slight loss of spirulina. Figure 7 showed that the photocurrent of the spirulina biosolar cell with $3.8 \mathrm{~g}$ sucrose in anode chamber was increased $389 \mu \mathrm{A}$ under the light for $4 \mathrm{~h}$.

The influence of other carbohydrates on photocurrent of the spirulina biosolar cell was investigated. The results were shown in Table 1 . The date indicated that glucose and chitosan made the photocurrent of the solar cell increase about $80 \mu \mathrm{A}$ 


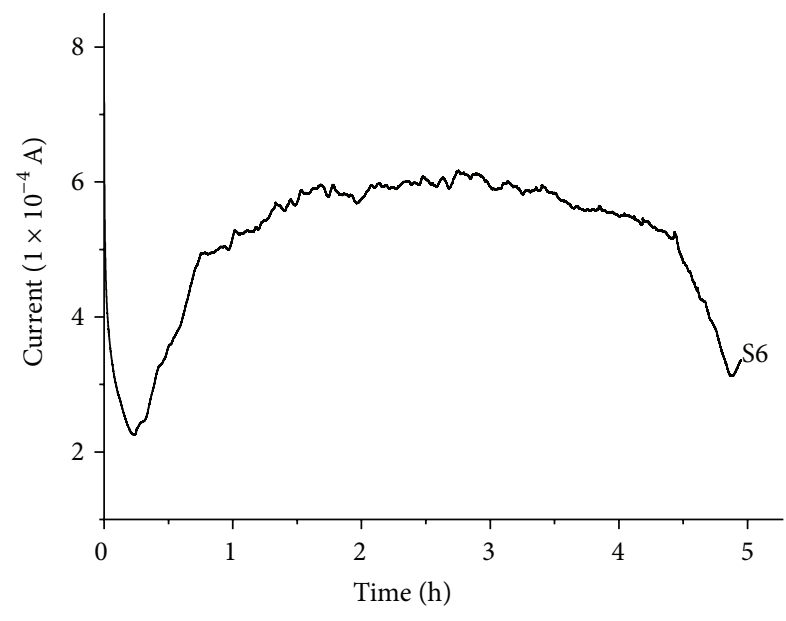

FIGURE 7: Current-time curve of the spirulina solar cell with sucrose under the light for $4 \mathrm{~h}$.

TABLE 1: Current of the biosolar cell with spirulina and carbohydrates.

\begin{tabular}{lccc}
\hline Anolyte & $I_{1}(\mu \mathrm{A})$ & $I_{2}(\mu \mathrm{A})$ & $\Delta I(\mu \mathrm{A})$ \\
\hline C & 20 & 39 & 19 \\
C + S & 32 & 102 & 70 \\
C + S + Glucose & 114 & 194 & 80 \\
C + S + Sucrose & 101 & 201 & 100 \\
C + S + Chitosan & 82 & 166 & 84 \\
\hline
\end{tabular}

C: culture medium, S: spirulina, $I_{1}$ : current at $900 \mathrm{~s}, I_{2}$ : current at $1900 \mathrm{~s}$, and $\Delta I$ : the photocurrent difference.

and $84 \mu \mathrm{A}$, respectively. Among them, the photoelectric conversion effect of the spirulina biosolar cell with sucrose was the best and could be improved approximately by $100 \mu \mathrm{A}$.

Carbohydrates might improve the photosynthesis rate and photoelectric conversion of the spirulina biosolar cell due to their improving of the activity of hexokinase (an enzyme relating to the cyanobacterial photosynthesis). In the process, the carbohydrates were likely to compensate for lack of a carbon source and conducive to consumption reducing of ATP and NADPH in carbon utilization of the cells. These exogenous carbohydrates provided electrons as the endogenous starch or glucose did and made the electrons flow to PS I. Meanwhile, they improved proton gradient of crossing thylakoid membrane, photosynthetic phosphorylation level of cell, and the efficiency of emitting electrons from spirulina.

\section{Conclusions}

Phycobiliprotein-squaraine composite had good efficiency for widening and strengthening the UV-Vis light absorption and fluorescence emission of $\mathrm{TiO}_{2}$ film and improving the photovoltage and photocurrent of the DSSC. Living spirulina had photoelectric conversion effect and could transmit the photoelectrons by its photosynthesis out of its cytomembrane in spirulina biosolar cell. Carbohydrates could improve the photocurrent of the solar cell further. Among them, sucrose was the best additive and could let the current and the power density of the spirulina biosolar cell increase by $100 \mu \mathrm{A}$ and $30 \mathrm{~mW} / \mathrm{m}^{-2}$, respectively. Spirulina biosolar cell will have a large potential for practical applications.

\section{Conflict of Interests}

The authors declare that they have no direct financial relation with the commercial identities mentioned in this paper that might lead to a conflict of interests for any of them.

\section{Acknowledgments}

The authors would like to thank Hebei Natural Science Foundation (no. B2011203231) and the Hebei Key Laboratory of Applied Chemistry Sea Grant (Yanshan University) for providing the financial support for this project.

\section{References}

[1] B. O'Regan and M. Grätzel, "A low-cost, high-efficiency solar cell based on dye-sensitized colloidal $\mathrm{TiO}_{2}$ films," Nature, vol. 353, no. 6346, pp. 737-740, 1991.

[2] P. V. Kamat and G. C. Schatz, "Nanotechnology for next generation solar cells," Journal of Physical Chemistry C, vol. 113, no. 35, pp. 15473-15475, 2009.

[3] L. Q. Wang, P. J. Wang, Y. Liu et al., "Near-infrared indocyanine materials for bioanalysis and nano- $\mathrm{TiO}_{2}$ photoanodes of solar cell," Journal of Nanomaterials, vol. 2013, Article ID 695107, 5 pages, 2013.

[4] T. F. Jiao, Y. Wang, Q. R. Zhang et al., "Preparation and photocatalytic property of gold nanoparticles by using two bolaform cholesteryl imide derivatives," Journal of Dispersion Science and Technology, vol. 34, no. 12, pp. 1675-1682, 2013.

[5] Y. X. Shi, R. B. Guo, X. H. Xu, and X. L. Fan, "Preliminary study on microalgae solar cell," Renewable Energy Resources, vol. 27, no. 3, pp. 15-17, 2009.

[6] H. He, Y. Feng, H. Li, and D. Li, "Construction of a microbial fuel cell using Chlorella vulgaris," The Chinese Journal of Process Engineering, vol. 9, no. 1, pp. 133-137, 2009.

[7] X. Y. Wu, C. X. Zhou, Y. F. Zhi, and L. Y. Chen, "Progress of microbial fuel cell with microalgae," Environmental Science and Technology, vol. 35, no. 4, pp. 82-86, 2012.

[8] Z. Yongjin, J. Pisciotta, R. B. Billmyre, and I. V. Baskakov, "Photosynthetic microbial fuel cells with positive light response," Biotechnology and Bioengineering, vol. 104, no. 5, pp. 939-946, 2009.

[9] S. T. Jiang, Y. J. Guan, S. L. Bai, and Y. C. Yang, "Electricity generation characteristics of microbial fuel cell using glucose as substrate," China Water and Wastewater, vol. 25, no. 23, pp. 38-40, 2009.

[10] M. C. Potter, "Electrical effects accompanying the decomposition of organic compounds," Proceedings of the Royal Society of London B, vol. 84, no. 571, pp. 260-276, 1911.

[11] T. Yagishita, S. Sawayama, K. Tsukahara, and T. Ogi, "Effects of glucose addition and light on current outputs in photosynthetic electrochemical cells using Synechocystis sp. PCC6714," Journal of Bioscience and Bioengineering, vol. 88, no. 2, pp. 210-214, 1999. 
[12] S. K. Chaudhuri and D. R. Lovley, "Electricity generation by direct oxidation of glucose in mediatorless microbial fuel cells," Nature Biotechnology, vol. 21, no. 10, pp. 1229-1232, 2003.

[13] B. E. Logan, "Simultaneous wastewater treatment and biological electricity generation," Water Science and Technology, vol. 52, no. 1-2, pp. 31-37, 2005.

[14] G. V. Subhash, R. Chandra, and S. V. Mohan, "Microalgae mediated bio-electrocatalytic fuel cell facilitates bioelectricity generation through oxygenic photomixotrophic mechanism," Bioresource Technology, vol. 136, pp. 644-653, 2013.

[15] E. Fernando, T. Keshavarz, and G. Kyazze, "Simultaneous co-metabolic decolourisation of azo dye mixtures and bioelectricity generation under thermophillic $\left(50^{\circ} \mathrm{C}\right)$ and saline conditions by an adapted anaerobic mixed culture in microbial fuel cells," Bioresource Technology, vol. 127, pp. 1-8, 2013.

[16] C. C. Lin, C. H. Wei, C. I. Chen, C. J. Shieh, and Y. C. Liu, "Characteristics of the photosynthesis microbial fuel cell with a spirulina platensis biofilm," Bioresource Technology, vol. 135, pp. 640-643, 2013.

[17] J. C. W. Lan, K. Raman, C. M. Huang, and C. M. Chang, "The impact of monochromatic blue and red LED light upon performance of photo microbial fuel cells (PMFCs) using chlamydomonas reinhardtii transformation F5 as biocatalyst," Biochemical Engineering Journal, vol. 78, pp. 39-43, 2013.

[18] G. L. Jin, S. B. Zhang, and H. Y. Wang, "The effect of vitamin C on growth of alga spirulina platensis," Fisheries Science, vol. 27, no. 4, pp. 203-204, 2008.

[19] F. F. Guo, W. Zong, and Y. W. Qu, "Prospects of development and use of spirulina," Science and Technology Information, vol. 6, pp. 16-16, 2008.

[20] Z. H. Song and G. I. Huang, "Toxicity of triphenyltin to Spirulina subsalsa," Bulletin of Environmental Contamination and Toxicology, vol. 64, no. 5, pp. 723-728, 2000.

[21] A. C. M. S. Esteban and E. P. Enriquez, "Graphene-anthocyanin mixture as photosensitizer for dye-sensitized solar cell," Solar Energy, vol. 98, pp. 392-399, 2013.

[22] R. A. Timmers, D. P. B. T. B. Strik, H. V. M. Hamelers, and C. J. N. Buisman, "Electricity generation by a novel design tubular plant microbial fuel cell," Biomass and Bioenergy, vol. 51, pp. 6067, 2013.

[23] R. A. Timmers, D. P. B. T. B. Strik, H. V. M. Hamelers, and C. J. N. Buisman, "Characterization of the internal resistance of a plant microbial fuel cell," Electrochimica Acta, vol. 72, pp. 165171, 2012.

[24] E. J. Olguín, "Phycoremediation: key issues for cost-effective nutrient removal processes," Biotechnology Advances, vol. 22, no. 1-2, pp. 81-91, 2003.

[25] L. Q. Wang, X. J. Peng, W. B. Zhang, F. Yin, J. N. Cui, and X. Q. Gao, "Synthesis and spectral properties of novel water-soluble near-infrared fluorescent indocyanines," Chinese Chemical Letters, vol. 16, no. 3, pp. 341-344, 2005. 

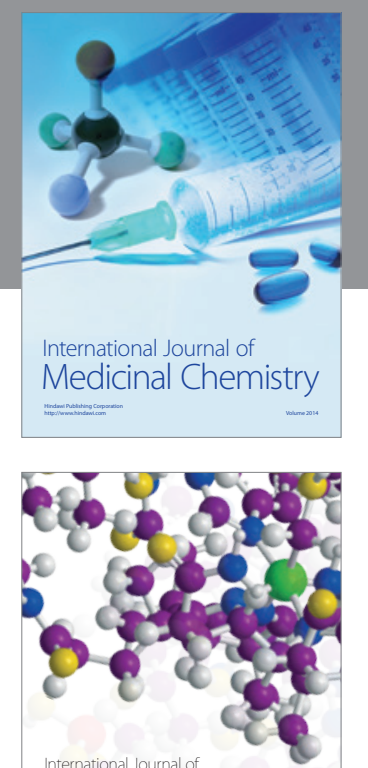

\section{Carbohydrate} Chemistry

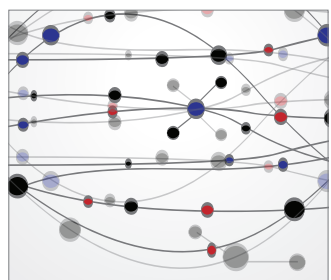

The Scientific World Journal
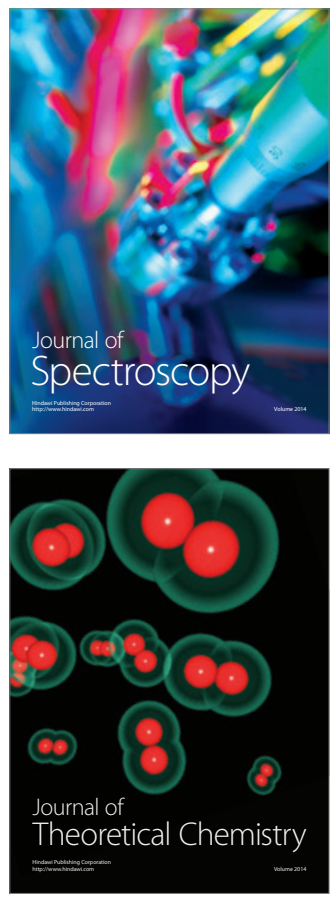
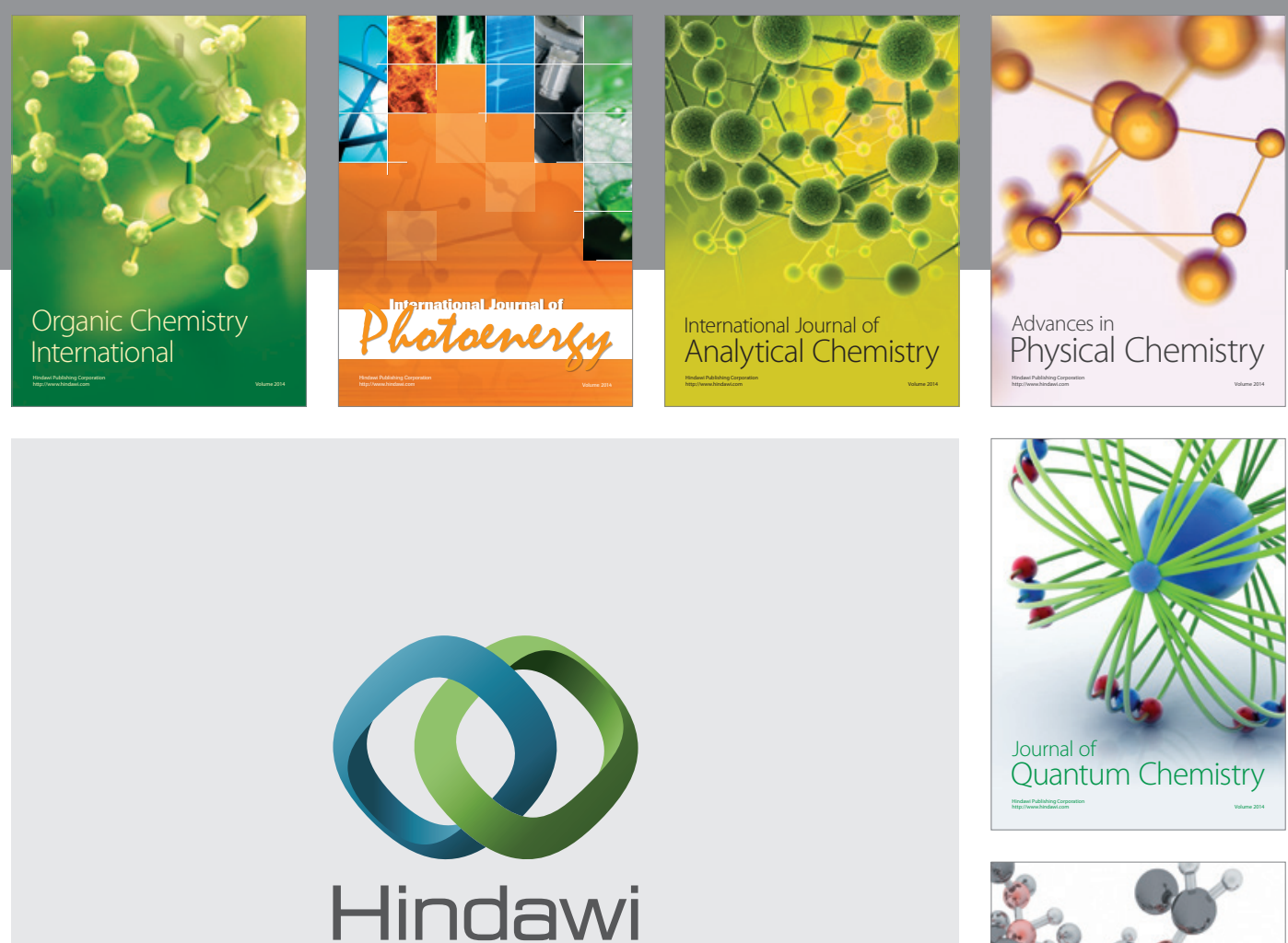

Submit your manuscripts at

http://www.hindawi.com

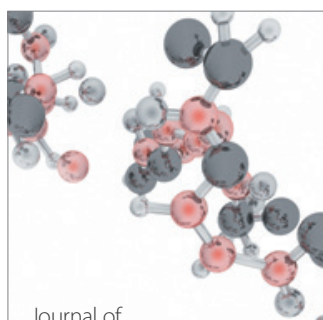

Analytical Methods

in Chemistry

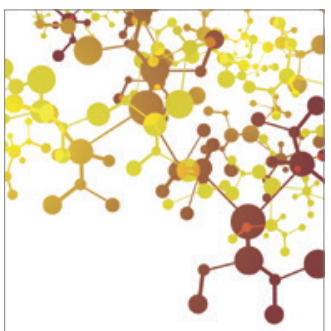

Journal of

Applied Chemistry

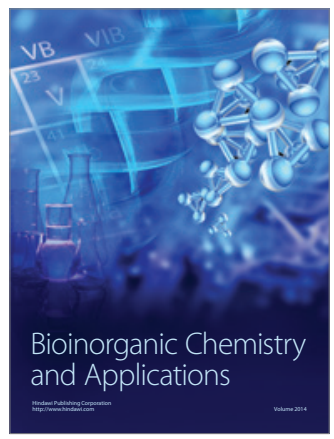

Inorganic Chemistry
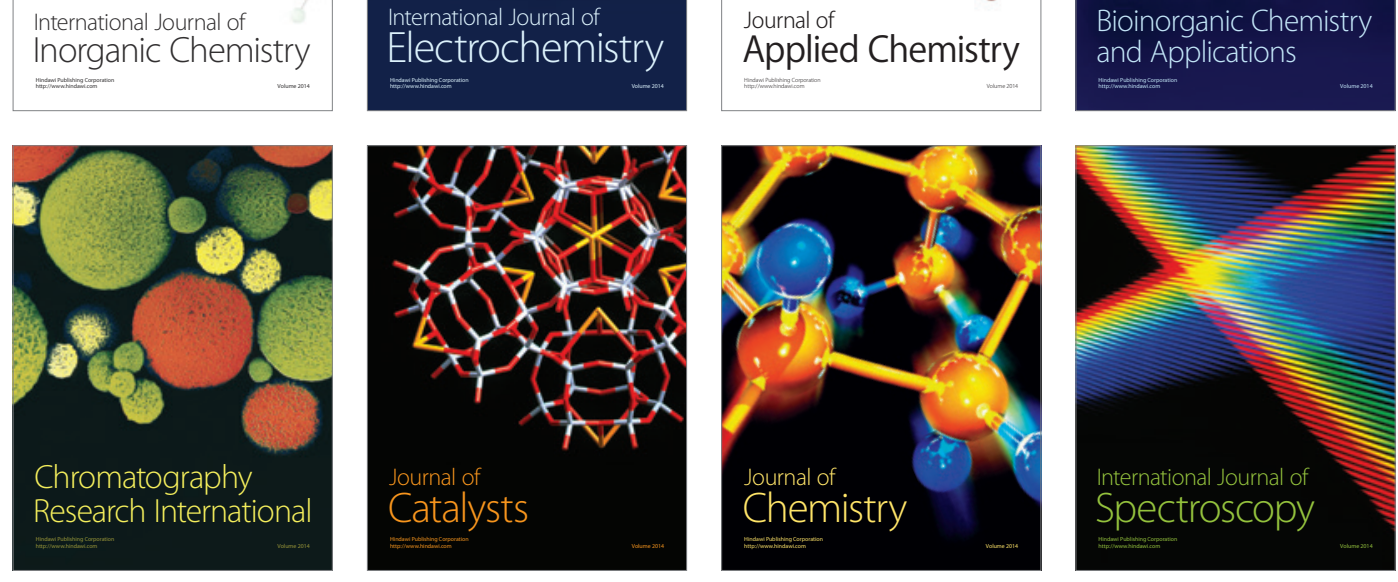